\title{
Enterprise Zone Effectiveness In California
}

\author{
Lee Hanson, California State University, San Bernardino, USA
}

\begin{abstract}
This case study looks at enterprise zones in California. Like most states, California had established an enterprise zone (EZ) program that offered businesses tax credits to encourage investment in depressed local economies. Yet despite nationwide adoption of enterprise zones, their efficacy as an economic development tool was disputed. In California, critics charged that costs had exploded without generating commensurate job growth and that EZs were a form of corporate welfare for large corporations that were the main recipients of tax credits. Obtaining reliable information about the benefits for local economies was difficult. The case explores this challenge in reporting results of a small study conducted by a local Southern California enterprise zone in the wake of calls by the state to eliminate the EZ program to help close a $\$ 25$ billion budget deficit. The case also illustrates the role enterprise zones may play in "incentive packages" offered by local governments seeking to attract national and multinational companies.
\end{abstract}

Keywords: Enterprise Zones; Economic Development; Tax Credits; Corporate Welfare

\section{INTRODUCTION}

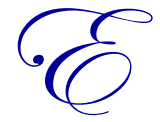

nterprise zones (EZ) are a state government economic development tool intended to revitalize economically distressed communities by providing tax and other incentives to encourage business growth. Enterprise zones began to be instituted by state legislatures in the early 1980s, and since then had proliferated nationwide. Typically, municipal or county governments were tasked with local administrative responsibility under authority of the state government, which designated enterprise zones and their boundaries.

Although EZs were well established as public policy, their impact in reviving local economies was still uncertain three decades after their inception. A review of the academic research concluded in 2005 that:

Most studies suggest no significant and prolonged increases in employment from enterprise zones....Five studies find no increases in jobs, while three studies find at least a temporary increase in jobs and income. What causes the differences in results is uncertain. It might be related to statistical method, the data used for analysis, the particular program, or the economy within and surrounding the zone (Hirasuna \& Michael, 2005, p. 11).

This ambiguous assessment had been echoed by several newer EZ studies (Greenbaum, 2009; Kolko \& Neumark, 2010). Uncertainty about the value of enterprise zones concerned state and local governments and businesses alike, albeit for differing reasons. State legislatures granting tax abatements to hire or invest within EZs wanted verification that foregone state tax revenues were recouping their costs and incentivizing businesses to generate economic growth beyond what the state would see otherwise. Local governments wanted to retain incentives they believed gave advantage to their jurisdictions in attracting business. Businesses that utilized EZ tax incentives or were interested in doing so hoped to preserve a government subsidy that could reduce their costs.

\section{CALIFORNIA'S ENTERPRISE ZONE PROGRAM}

California enacted enterprise zone legislation in 1984, and as of 2012 had authorized 42 EZs around the state. Most were within single municipalities, but some spanned municipal or city-county boundaries, in which case a local joint-powers or multi-jurisdictional authority in some form was created to oversee the zone. Local economic development personnel normally had responsibility for day-to-day operation and ensuring compliance with state requirements. The existing enterprise zones are listed in Figure 1. 
Designation as an enterprise zone occurred through a competitive process in which the state agency responsible for the program, the California Department of Housing and Community Development, solicited applications from interested municipal and county agencies. Jurisdictions had to meet specified information and scoring criteria demonstrating that the area of their proposed zone satisfied requirements of the EZ legislation for economic distress, measured by factors like income and poverty levels. Winning jurisdictions of a given application "round" received EZ designation for 15 years. Application rounds occurred when existing EZ's lapsed or if the state legislature authorized additional zones, which had occurred a number of times since the program began. Two of the zones were slated to expire in 2012.

\begin{tabular}{|c|c|}
\hline \multicolumn{2}{|c|}{ California Enterprise Zones in 2011} \\
\hline Northern California & $\underline{\text { Southern California }}$ \\
\hline$\overline{\text { Arvin }}$ & $\overline{\text { Anaheim }}$ \\
\hline Delano & Antelope Valley \\
\hline Eureka & Barstow \\
\hline Fresno (city) & Calexico - Imperial County \\
\hline Fresno (county) & Coachella Valley \\
\hline Kings County & Compton \\
\hline Merced Regional & Harbor Gateway Communities \\
\hline Oakland & Hesperia \\
\hline Oroville & Imperial Valley \\
\hline Pittsburg/Bay Point & Long Beach \\
\hline Porterville & Los Angeles, East \\
\hline Richmond & Los Angeles, Hollywood \\
\hline Sacramento & Pasadena \\
\hline Salinas Valley & San Bernardino Valley \\
\hline San Francisco & San Diego Regional \\
\hline San Joaquin & Santa Ana \\
\hline San Jose & Santa Clarita Valley \\
\hline Sequoia Valley & Southgate - Lynwood \\
\hline Shasta County & \\
\hline Siskiyou County & \\
\hline Stanislaus (Ceres, Modesto, Stanislaus County, Turlock) & \\
\hline Taft & \\
\hline West Sacramento & \\
\hline Yuba - Sutter & \\
\hline
\end{tabular}

Enterprise zones offered businesses several tax credits. These included a Sales or Use Tax Credit for the tax liability incurred on purchase of up to $\$ 20$ million of qualifying equipment, and a Net Operating Loss carryover provision. However, the benefit claimed most frequently was a Hiring Tax Credit for employing disadvantaged workers. The EZ program was intended not simply to stimulate new job-creation, but to encourage greater hiring of state residents who faced barriers to work. Businesses could receive a total of $\$ 37,440$ for each such employee over a period of five years.

Claiming the Hiring Tax Credit entailed a vouchering process in which "Qualified" or disadvantaged employees were certified by the local government entity responsible for the EZ as meeting any of several eligibility criteria. These included job loss, disability, qualification for federal Job Training Partnership assistance, veteran or ex-offender status, or residence in a state-designated Targeted Employment Area (TEA). TEAs generally corresponded to the boundaries of enterprise zones, but there were also some that were separate from EZs. In practice, TEA residence was the basis for approving a majority of hiring vouchers. To qualify, an individual might be a resident of any TEA; they need not actually live in the enterprise zone in order for their employer to claim the tax credit. Additionally, existing employees who met eligibility criteria could be claimed retroactively, hence in such circumstances a business could receive the tax credit even though no new job was actually created. Hiring Tax Credits were claimed at the time businesses filed tax returns with the state Franchise Tax Board, utilizing a designated form (3805Z). 


\section{LOCAL ENTERPRISE ZONE INCENTIVES}

As a condition for receiving an enterprise zone designation, local governments were required to complement state tax credits with local financial incentives and benefits targeted specifically to enterprise zone businesses. Local incentives had to be enumerated in EZ applications. The greater their value, the better a jurisdiction would do in application scoring.

A variety of local incentives were found across the state. Financial incentives for building or expanding facilities in an enterprise zone included development and planning fee reductions, deferrals, or waivers. Sales taxsharing might also be offered. California sales tax was 7.25 percent, of which 1 percent was returned by the State Board of Equalization to the jurisdiction in which the tax originated. Sharing of some portion of the 1 percent with businesses sometimes had occurred. Non-financial incentives included so-called "one-stop" planning and permitting services, "fast-tracking" of plans and inspections, and economic development technical assistance for such things as workforce training or market analysis.

Local jurisdictions were required to market their enterprise zones to encourage participation by businesses located within the zone, and to establish partnerships with local banking, real estate, education, and other business service providers who could assist enterprise zone businesses. A particularly important service was helping small employers understand state requirements for claiming EZ incentives. Tax credit paperwork was alleged to be so burdensome for small firms that it was thought many who were eligible for EZ tax credits declined to claim them. Hence a need for ongoing outreach to small businesses by local EZ program managers, typically in the form of periodic tax credit workshops conducted by qualified consultants. Large corporations tended to have the accounting resources, and often experience filing for EZ tax credits, that enabled them to take full advantage of them.

\section{SIZE OF PARTICIPATING BUSINESSES}

Two distinct types of business were found in enterprise zones: small ones which predominated, and a sprinkling of larger ones. The former were overwhelmingly locally-owned and operated, and often had been in operation prior to the establishment of the EZ. They varied greatly in terms of industry sector and whether or not they mainly served the local market or exported beyond it, but they were conspicuous for small employment, limited capitalization, and more often than not, limited growth potential.

The handful of large-size businesses in a typical zone usually were establishments of national or multinational corporations, some of which may have been attracted to locate there in part because of EZ incentives. These branch plant businesses also spanned the gamut of industries. While in any given instance they could be small establishments - for example, a local office of a nationwide financial services company - if larger-sized, they were likely to be among the largest employers located within an EZ. They were particularly sought after by local authorities and economic developers because of their potential to inject a significant number of new jobs into the local economy. They also were usually export-oriented, selling nationally or internationally, with corresponding potential to grow and to eventually add still more employment.

Nationwide, local government economic development agencies engaged in ongoing efforts to attract large employers to their jurisdictions (LeRoy, 2005). In an environment of intense inter-jurisdictional competition, national or multinational corporations were often astute at maximizing the value of financial incentives negotiated with local jurisdictions seeking to attract new employers. Enterprise zones were one factor businesses might take into consideration in location decisions, especially if income levels of the local population were not a concern. Local incentives were another consideration, and many firms considering sites in adjacent localities could be aggressive in bargaining with jurisdictions for the best "incentive package." In turn, communities were often assertive in trying to out-compete neighbors for a prospective employer.

\section{ECONOMIC DEVELOPMENT OR CORPORATE WELFARE}

Persisting questions about the value of California's enterprise zones surfaced in 2010 when a senate bill proposed cutting the Hiring Tax Credit to fund alternative education programs. The bill failed, but subsequently, 
newly-elected Governor Jerry Brown proposed eliminating enterprise zones altogether as part of a plan to close a $\$ 25$ billion budget deficit, a proposal that was based in part on doubts about their value raised by the state Legislative Analyst's Office, which had recommended elimination in the past.

The governor's proposal coincided with release of a scathing report by the non-profit California Budget Project (CBP) asserting that cost of EZ tax credits had risen dramatically without generating commensurate increases in employment, or so the report claimed citing academic research (California Budget Project, 2010). According to the CBP, enterprise zones cost the state $\$ 465.5$ million in 2008 compared to $\$ 675,000$ in 1986 , a rate of growth averaging 35 per cent per year. Average cost per zone had also risen dramatically, from $\$ 48,000$ in 1986 to $\$ 11.1$ million in 2008. Corporations with assets of $\$ 1$ billion or more had received 70 percent of $\mathrm{EZ}$ tax credits in 2008 , although less than half of 1 percent of corporations filing tax returns in the state had $\$ 1$ billion or more in assets. Businesses with less than $\$ 1$ million in assets claimed just 1.6 percent of tax credits that year. Hence, few EZ tax credits were going to small businesses located in enterprise zones. The Hiring Tax Credit accounted for \$273.5 million in 2008 or 58.7 percent of the total cost of EZ credits. Although the CBP's report did not address the issue, the bulk of Sales/Use Tax credits would also have been claimed by large firms.

The CBP report was controversial and brought prompt rebuttal from proponents of enterprise zones. One, the California Association of Enterprise Zones, pointed to a set of studies posted on its web site that it maintained documented the value of enterprise zones demonstrated over 20 years. One of these reports, prepared for the state Assembly in 2006 by the Housing and Community Development Department, reported higher growth rates in household incomes and salaries within enterprise zones than outside of them, as well as greater decline in poverty and unemployment rates.

Supporting studies were themselves not definitive, so they did little to quell criticisms of enterprise zones, or charges that EZs were a form of "corporate welfare." Nonetheless, enterprise zones had strong supporters in business and the legislature. They lobbied successfully to preserve the program, which continued in 2012. In acknowledgement of criticisms as well as current state budget realities, administrative rules for enterprise zones were being reviewed by the Housing and Community Development Department with the aim of reducing costs of the Hiring Tax Credit, possibly by limiting eligibility to newly-created jobs only.

\section{DATA AVAILABILITY}

Businesses in enterprise zones could always be tapped to provide testimonials about the value of EZ incentives. But in the absence of conclusive evidence that EZ's were as good a deal for jurisdictions and taxpayers as they were for businesses, local economic developers felt a chronic inability to prove that EZ incentives were as economically vital to their communities as they believed them to be.

The legislative proposal in 2010 to eliminate the Hiring Tax Credit led one Southern California enterprise zone to undertake a study that it hoped legislative supporters could use to show the economic value of the EZ program. Because of limited time and resources and lack of availability of secondary data about the local economy comparable to that available for the national economy, the project was conceived as a case study that would collect and analyze data for payroll, purchasing, hiring, and EZ tax credits volunteered by local firms within the enterprise zone. Without necessarily performing formal statistical analysis, the data could be examined for evidence that EZ tax credits had some positive association with business location decisions and sales and hiring growth within the zone, both of new employees overall and of disadvantaged workers. Operating expense data would give some indication of the economic impact of the firms in terms of the value of their payroll and purchasing.

A basic assumption of the sponsoring agency, and of EZ program managers statewide, was that reduction or elimination of EZ tax credits could result in businesses choosing to leave the zone or the state. As this was a hypothesis that could not be proven since California's EZ incentives had not been eliminated, it could be addressed only by querying businesses about the likelihood of their leaving if incentives disappeared. In designing an interview protocol for collecting data, relocation intentions of businesses as well as their perceptions of benefits of EZ tax credits were addressed through five Likert-type questions in which businesses answered using a scale of 1 to 5, in which 1 indicated strong agreement with a question, 5 strong disagreement. The questions asked whether EZ 
tax credits had contributed to growth of production, defined as increased volume of units sold; whether the Hiring Tax Credit had provided a meaningful incentive to hire disadvantaged workers; whether businesses were aware of the Sales/Use Tax Credit in purchasing qualified equipment; whether the business would have left the state if there were no enterprise zone; and whether it would leave if the enterprise zone program was eliminated.

Businesses were also asked to provide the Hiring Tax and Sales/Use Tax Credit figures reported on their $3805 Z$ tax forms for the years 2007, 2008, and 2009 (the EZ went into effect in 2006). For the same three years, they were asked for their total annual payrolls, purchasing expenditures, average hourly wages paid to Qualified and non-qualified employees (the latter being non-disadvantaged workers for whom no Hiring Tax Credit can be claimed), and total number of Qualified and non-qualified employees.

Participants were recruited by the local enterprise zone manager through contacts established in administering employee vouchering. The intent was to involve as many businesses as possible, with a target of several dozen that would be of varying size ("small" defined as 100 or fewer employees, "medium" defined as 100 500 employees, "large" defined as more than 500 employees). A variety of industries was sought, along with a mix of businesses that were both long-established in the community and that had moved to it more recently.

In the event, just eight firms agreed to participate, all of which were small except for a medium-sized one. Seven of the eight were established in the community before the enterprise zone was designated in the mid-2000s. No corporate branch plants participated. This small, insufficiently representative sample seriously limited the value of the findings since it failed to include any of the minority population of large firms that were the major users of EZ credits. In hindsight, this was probably unsurprising given that participation entailed sharing confidential business information. One business, a subsidiary of a foreign-based corporate parent that would have constituted a large business as defined by the study, initially agreed to participate, then withdrew after its accounting firm reviewed the information requested and advised against it.

The participants did represent a range of industries: commercial truck repair, construction supplies, electrical control manufacturing, environmental remediation, food distribution, window fabrication and sales, motorcycle sales, and steel safe manufacturing. While the study was compromised by the lack of participation of any larger firms, the findings still served to shed some light on how EZ incentives influenced (or failed to influence) the behavior of businesses located in California enterprise zones.

\section{FINDINGS AND INTERPRETATIONS}

A first finding concerned business perceptions of the value of the enterprise zone program, presented in Figure 2. Most tellingly, assumptions about prospects of business relocation if EZ incentives were eliminated were not borne out, as only one of the eight businesses said it would do so, a manufacturer that had moved into the area within the past few years. Given the absence of any corporate divisions or subsidiaries in the sample, there were no data to indicate what their intentions might be if EZ incentives were no longer available. But for the small respondents, economic and social connections to the local economy were clearly more important than the EZ tax credits they could claim.

\begin{tabular}{|l|c|}
\hline \multicolumn{2}{|c|}{ Responses to Likert Scale Questions } \\
\hline 1. EZ tax credits have contributed significantly to expansion of production. & 2.9 \\
\hline 2. Hiring Tax Credits have been a meaningful incentive to hire qualified worker. & 1.4 \\
\hline 3. Business has been aware of Sales or User Credit in buying equipment. & 1.4 \\
\hline 4. Without EZ credits, business would have moved out of California. & 4.5 \\
\hline 5. If EZ credits were eliminated, business would consider leaving California. & 4.3 \\
\hline Scale: 1 = strong agreement, 5 = strong disagreement & \\
\hline
\end{tabular}

\section{Figure 2}

The participants also indicated that EZ incentives had not had a particularly significant effect on level of business production - in other words, incentives were not felt to have stimulated significant business or job growth. A few reported claims for the Sales/Use tax, but in relatively modest amounts. However, the Hiring Tax Credit was 
reported to be a meaningful incentive for hiring Qualified workers, as was borne out by other findings of the survey. The Likert Scale questions thus suggested that for these small firms which had availed themselves of them, EZ tax credits were a useful benefit but not apparently one that had significantly affected scale of production or growth.

Figure 3 presents data on business expenditures on payroll and purchasing. The main point to be made about these data is in the context of the sponsor agency's assumption about likelihood of businesses relocating with elimination of EZ incentives. Averaged for the three years 2007 - 2009, the eight firms had a combined total payroll and purchasing outlay of \$136 million per year. Loss of this level of spending would have been a hard blow to the local economy if the firms all departed. While participants indicated that this was unlikely, once again, corporate subsidiaries might have answered differently. If larger firms were to be more likely to leave the area following an end to EZ incentives, the loss of their payroll and purchasing dollars would be devastating to the local economy.

\begin{tabular}{|l|r|}
\hline \multicolumn{2}{|c|}{ EZ Payroll and Purchasing Expenditures (3-year average 2007 - 2009) } \\
\hline Average EZ payroll & $\$ 3,233,369$ \\
\hline Maximum EZ payroll & $9,400,000$ \\
\hline Minimum EZ Payroll & 162,850 \\
\hline Total annual EZ payroll for all 8 firms & $25,866,954$ \\
\hline Average EZ purchasing & $13,809,000$ \\
\hline Maximum EZ purchasing & $63,240,000$ \\
\hline Minimum EZ purchasing & 249,700 \\
\hline Total annual EZ purchasing for all 8 firms & $110,471,726$ \\
\hline Total annual EZ payroll plus purchasing for all 8 firms & $\$ 136,338,680$ \\
\hline
\end{tabular}

Figure 3

Figure 4 presents employee counts and number of Qualified employees. Two insights from these data were noteworthy. First, employees who qualified for the Hiring Tax Credit averaged 11 percent among the eight businesses, a meaningful share. Additionally, the average number of Qualified employees doubled between 2007 and 2009, rising from 8 to 16 . Although this figure was somewhat misleading in that most of the hiring occurred in the one business in the group that had a high growth rate and was expanding, most of this involved new hiring, not retroactive vouchering of existing Qualified employees.

A second point about the staffing data concerns the impact of recession. Between 2007 and 2009 , employment among the eight firms fell 23 percent, from 902 to 694 . One firm accounted for most of the job loss, a retailer that was the largest business in the study. Two businesses that shed workers said that Hiring Tax Credits had led them to retain personnel who otherwise might have been discharged.

\begin{tabular}{|l|c|}
\hline \multicolumn{1}{|c|}{ Employee Counts (3-Year Average 2007 - 2009) } & 108 \\
\hline Average total employees & 12 \\
\hline Average total Qualified employees & 311 \\
\hline Maximum total employees & 20 \\
\hline Minimum total employees & 24 \\
\hline Maximum Qualified employees & 3 \\
\hline Minimum Qualified employees & $11 \%$ \\
\hline Average \% of Qualified employees & $56 \%$ \\
\hline Maximum \% of Qualified employees & $6 \%$ \\
\hline Minimum \% of Qualified employees & \\
\hline \multicolumn{1}{|c|}{ Average number of Qualified employees hired in: } \\
\hline 2007 & 8 \\
\hline 2009 & 16 \\
\hline Total employees among eight firms 2007 & 902 \\
\hline Total employees among eight firms 2009 & 694 \\
\hline Total Qualified employees 2007 & 61 \\
\hline Total Qualified employees 2009 & 125 \\
\hline
\end{tabular}

\section{Figure 4}


Figure 5 presents wage comparisons between Qualified and non-qualified employees. Again averaging the three years of the study, employees that qualified the firm to claim the Hiring Tax Credit earned 25 percent less than those who did not. This finding might be interpreted in either of two ways. One was that businesses might have felt able to pay Qualified workers less than others because of their officially disadvantaged status. But the more likely interpretation is that the Hiring Tax Credit encouraged hiring of more lower-paid entry-level workers who otherwise might not have been employed. In that case, the program was fulfilling one of the goals of the EZ legislation to increase job opportunities for disadvantaged workers. The pay data were weak in that they were limited to hourly wage only and did not include benefits. Also, the study was unable to determine whether, in one instance involving the largest firm, manager wages were included with those of non-management employees. But taking the wage figures with due caution, the pay differential observed in the sample firms raised the question of whether this difference was commonplace among businesses located in enterprise zones. If they were, were such wage differences a cause for concern for policy makers, or was the program incentivizing hiring of disadvantaged workers as it was intended to do?

\begin{tabular}{|l|r|}
\hline \multicolumn{1}{|c|}{ Average Hourly Wage (3-Year Average 2007 - 2009)* } \\
\hline Average wage non-qualified employees & $\$ 18.66$ \\
\hline Average wage Qualified employees & 28.36 \\
\hline Maximum wage Non-Qualified employees & 25.11 \\
\hline Maximum wage Qualified employees & 10.08 \\
\hline Minimum wage Non-qualified employees & $\$ 8.59$ \\
\hline Minimum wage Qualified employees & \\
\hline *Wages only, does not include benefits (7 firms) & \\
\hline
\end{tabular}

Figure 5

Figure 6 presents data reported for dollar value of Hiring Tax Credits generated by the businesses, averaged for the three years 2007 - 2009. These results were somewhat ambiguous; they indicated that businesses averaged about $\$ 70,000$ annually in credits generated or about $\$ 500,000$ annually for all eight firms, but in reality, few of the businesses had been able to claim the credits to reduce their taxes in one or more years because net business income had been too low to permit it, a consequence of recession. The Hiring Tax Credit therefore could have brought little direct financial benefit to the firms in the recent past. Likewise, the potential cost to the state of the Hiring Tax Credits generated was much less than the actual credits claimed. The finding was most significant as an indication of costs of EZ credits being claimed by the businesses which the state was likely to pay once the economy improved.

\begin{tabular}{|l|r|}
\hline \multicolumn{2}{|c|}{ Hiring Tax Credits Generated (3-year average 2007 - 2009) } \\
\hline Minimum annual Hiring Tax Credit generated per firm: & $\$ 6,992$ \\
\hline Maximum annual Hiring Tax Credit generated per firm: & 216,470 \\
\hline Average annual Hiring Tax Credit generated per firm: & 68,255 \\
\hline Average annual Hiring Tax Credit generated per employee: & 5,688 \\
\hline Total Hiring Tax Credit generated annually for all 8 firms: & $\$ 546,038$ \\
\hline
\end{tabular}

\section{Figure 6}

\section{CONCLUDING COMMENTS}

In the end, the study - which was rare in obtaining internal business operating data, inconclusive due to the skewed sample - was like so much EZ research: it settled little or nothing about whether enterprise zones stimulated economic growth or hiring of disadvantaged workers in levels that were worth the cost of tax credits to the state. On went the debate.

In early 2012, the city controlling the enterprise zone entered into negotiations with a national retail chain that planned to build a new regional warehouse to supply the Southern California market. The site the chain was considering was located in the enterprise zone. Although the facility would employ only about 150 people at relatively low wages and benefits, it was to include a retail point of sale where sales tax would be charged on items sold in the store portion of the warehouse. The projected annual sales tax the city would receive from the State Board of Equalization was $\$ 750,000$, enough to make the proposition attractive. 
However, the company wanted a sales tax-sharing arrangement that would give it 40 percent of the sales tax income returned to the city for 20 years. A similar arrangement had been established for another national firm that had located in the enterprise zone. While $\$ 450,000$, rather than $\$ 750,000$, was still lucrative, it was less so weighed against the increased truck traffic on city streets from the site to a nearby freeway onramp and the associated long-term street-maintenance costs. The business had hinted that a neighboring city was prepared to accept the tax-sharing proposal. However, it was outside the enterprise zone, which meant that the business would not be able to claim Hiring Tax Credits for Qualified employees or Sales/User Tax Credits for equipment investment. For the company, which incentive might be more valuable, sales-tax sharing versus the Hiring tax Credit, would depend on how many Qualified employees it could expect to employ.

City negotiators well understood that failure to present a "competitive" incentive package could cost them a new employer they wanted. But they also appreciated that forecasts of tax revenues, job-creation, and employee incomes were optimistic projections dependent upon success of the business, something that could not be guaranteed. For the same reason, projections of the cost-benefit ratio of tax-sharing relative to street maintenance costs must be speculative. The city wanted to be competitive, but the incentive package it offered needed to pencil out, to the extent that could be determined.

Although no date had been set, both parties expected to meet again to see whether they could reach terms that would be mutually agreeable to the company and to the city.

\section{AUTHOR INFORMATION}

Lee Hanson is Professor of Management, Emeritus at California State University, San Bernardino. His research interests include regional economic development and toxic or destructive leadership in executive management. He has consulted with California local governments about enterprise zones. His $\mathrm{Ph} . \mathrm{D}$. is from the University of California at Irvine. E-mail: $\underline{\text { lhanson@csusb.edu }}$

\section{REFERENCES}

1. California Budget Project (2011). California's Enterprise Zone Program: No Bang for the Buck. Sacramento, CA. Retrieved from: http://www.cbp.org/pdfs/2011/110207 Enterprise \%20Zones.pdf

2. Greenbaum, R. (2009). Why Are State Policy Makers Still Proponents of Enterprise Zones? What Explains Their Action in the Face of a Preponderance of the Research? International Regional Science Review, 32(4), 466 - 479.

3. Hirasuna, D. \& Michael, J. (2005). Enterprise Zones: A Review of the Economic Theory and Empirical Evidence. Policy Brief, Minnesota House of Representatives. Retrieved from: http://www.house.leg.state.mn.us/hrd/pubs/entzones.pdf

4. Kolko, J. \& Neumark, D. (2010). Do Enterprise Zones Create Jobs? Evidence from California's Enterprise Zone Program. Journal of Urban Economics, 68 (1), 1 - 19.

5. LeRoy, G. (2005). The Great American Jobs Scam: Corporate Tax Dodging and the Myth of Job Creation. San Francisco: Berrett-Koehler. 